\title{
The Waqf Legal Politics in Law Reform Perspective
}

\section{Okky Prastyo Ajie *) and Arpangi **)}

*) Faculty of Law, Sultan Agung Sultan Agung Islamic University, E-mail: okk1pras@gmail.com

${ }^{* *}$ Faculty of Law, Sultan Agung Sultan Agung Islamic University

\begin{abstract}
.
This study aims to analyze the previous ijtihad fuqaha towards the designation of waqf land was aimed at the benefit of the people in accordance with the social conditions at that time. Likewise, the ijtihad of Indonesian scholars towards the development of waqf objects is for the benefit of mankind which is adapted to the needs and social settings at this time. Because basically the law is the articulation of human thought and activity in his life. Legislation is the main way of creating laws. Regulations is the main joint of the national legal system in Indonesia. The research method used by the author is normative juridical research. This scientific method approach is used to find the truth based on the theory of normative legal experts. In addition, legislation is a very effective instrument in law reform because of its binding and coercive legal force. Legal politics has a very important role in the formation of laws and regulations and Indonesian national law, considering that legal politics is used as a basic guide in the process of determining values, establishing and developing national law in Indonesia. Waqf as an institution derived from Islamic law plays an important role in the religious and social life of Muslims. In conclusion, the waqf legal regulations that are applied to Indonesian Muslims today can be found in book III of the Compilation of Islamic Law (KHI) and Act No. 41 of 2004 concerning Waqf.

Keywords: Benefit; Politics; Reformation; Waqf.
\end{abstract}

\section{Introduction}

Every country has legal politics whose role is as a basic policy for state administrators to determine the direction, form and content of the law to be formed. As the understanding of legal politics according to Padmo Wahjono by saying that legal politics is the policy of state administrators about what is used as criteria for punishing something which includes the formation, application and enforcement of the law. ${ }^{1}$.

The problem is how state administrators manage it. There are countries that plan and systematically develop their legal politics, and wish to completely reorganize the legal order either for ideological reasons or because of changes in the political system. Likewise with waqf, waqf as an Islamic teaching that has both worship and social dimensions is actually familiar to the Muslim community, including in Indonesia. In general, people are more familiar with the term Waqf only for Muslims (people who are Muslim), the existence of Waqf in Indonesia is used for mosques, prayer rooms, schools, houses, jariyah, agricultural land, orphans, tombs and a lot of waqf land which is managed in an organized manner,

${ }^{1}$ Padmo Wahjono, 1986, Indonesia Negara Berdasarkan Atas Hukum, Jakarta: Ghalia Indonesia, p. 160 
productive in the form of something whose results can be used for those who need it, especially the poor ${ }^{2}$.

This utilization is seen from a social perspective, especially for worship purposes, it is indeed effective, but so far waqf as a maliyah worship has not become an institution that is widely practiced by the community, especially in Indonesia. In fact, the promised jariyah reward behind the practice of waqf should be a separate motivation for fertilizing waqf activities in society. In addition, the social dimension of waqf seems very relevant in unraveling the social problems of Muslims today such as poverty, health and education as well as other problems that are closely related to the economic field. Through these two dimensions, worship and social, waqf has a strategic position in Islamic teachings and is important to continue to be developed ${ }^{3}$.

Management and development of Waqf in Indonesia needs a joint commitment from the government, ulama and society. In addition, it must also be reformulated regarding various matters relating to waqf, including the property being waqf, the designation of waqf and Nadzir and the management of waqf in a professional manner. Waqf goods should not be limited to immovable objects only, but also movable objects such as cash waqf (money), shares and others. In addition, waqf must be handed over to people or a special body that has sufficient competence so that it can manage it professionally and in a trustworthy manner. The enactment of Act No. 41 of 2004 concerning Waqf, is an Indonesian fiqh as a result of the ijtihad of Indonesian scholars in accordance with the needs and social rules at that time, but the ijtihad of the Indonesian ulema cannot cancel the ijtihad of the previous fiqh scholars. The previous ijtihad fuqaha towards the designation of waqf land was aimed at the benefit of the people in accordance with the social conditions at that time ${ }^{4}$.

Likewise, the ijtihad of Indonesian scholars towards the development of waqf objects is for the benefit of mankind which is adapted to the needs and social settings at this time. Because basically the law is the articulation of human thought and activities ${ }^{5}$. Meanwhile, the dynamics of human life are always changing. Therefore, from the development of waqf land designation, it is necessary to look for the philosophical value or according to Fazlul Rahman's term "Ideal Moral" from the development of the waqf land designation. When the development of waqf land designation is transformed into a practical level without looking at the basic value of the waqf, it can lead to deviations from the purpose of the waqf itself6.

\footnotetext{
2 Ong Argo Victoria, "Waqf Al-Nuqūd In Indonesia (In Law Perspective)", Jurnal Pembaharuan Hukum Vol 5, No 1 Universitas Sultan Agung, http://jurnal.unissula.ac.id/index.php/PH/article/view/2999

${ }^{3}$ Adijani AI-Alabij, 1989, Perwakafan Tanah dl Indonesia Dalam Teori dan Praktek, Jakarta: Rajawali and Ahmad Azhar Basyir, 1987, Hukum Islam tentang Wakaf, Ijarah Syirkah, Bandung: Alma'arif, p.98

${ }^{4}$ Ahmad Rofiq, 1977, Hukum Islam di Indonesia, Print. II; Jakarta: Raja Grafindo Persada, p.xi

5 Ahmad Chulemi, 1987, Hukum Agraria Perkembangan Macam-Macam Hak Atas Tanah dan Pemindahannya, Semarang: Faculty of Law UNDIP, p.76

${ }^{6}$ Ibid
} 


\section{Research Methods}

The research method used by the author is normative juridical research. This scientific method approach is used to find the truth based on the theory of normative legal experts obtained from secondary legal sources such as legislation and literature related to the object of research. The specifications of the research are descriptive. Provide an overview and critical analysis and conclusions of the research object. Sources of data using secondary data sources through books and legislation. Methods of data collection using literature study. The data analysis method uses a qualitative approach ${ }^{7}$.

\section{Results and Discussion}

\subsection{History of Waqf Development in Indonesia}

The history of the development of waqf in Indonesia is in line with the spread of Islam throughout the archipelago. Although waqf in Indonesia has been known and implemented since the beginning of the entry of Islam in Indonesia. The scholars such as Walisongo, who taught waqf to the people. However, its implementation is still traditional and adapted to existing customs in the community. This is marked by the establishment of mosques built on waqf land. But unfortunately with the increase in the number of waqf lands, it is not accompanied by the rules that govern it. This results in waqf not being able to develop properly and even tend to cause problems ${ }^{8}$.

After Indonesia's independence, the government issued several waqf regulations. Among them are Government Regulation No. 28 of 1977 concerning the waqf of owned land, PMA No. 1 of 1978 concerning implementing regulations of Government Regulation No. 28 of 1977 concerning the waqf of owned land, the Compilation of Islamic Law, and others. Although there have been several regulations issued by the government to regulate waqf, it turns out that waqf in Indonesia has not been developed optimally. Therefore, with the enactment of Act No. 41 of 2004 which was followed by Government Regulation No. 42 of 2006 is expected to be able to answer the problems regarding the previous waqf.

\subsubsection{Waqf Regulations During the Early Entry of Islam to the Dutch Period}

Islam entered the archipelago in the 7th century AD. Before the arrival of Islam, people had actually carried out humanitarian actions that resembled waqf, namely giving land and then used it for the public interest. Donations made by the community because in their lives, they always connect worldly problems with religious or spiritual problems. After the arrival of Islam which taught waqf since the time of the Prophet, the caliphate and Islamic dynasties until now waqf is still carried out from time to time in all Muslim countries, including in Indonesia. This can be seen from the fact that the waqf institution originating from Islam has been

\footnotetext{
7 Pradikta Andi Alvat, (2019) Politic of Law Human Rights Protection, Indonesia Jurnal internasional Daulat Hukum Vol.2 No.4 url:http://jurnal.unissula.ac.id/index.php/RH/issue/view/398

8 Sukarmi, S., \& Victoria, Argo. (2018). Cash Waqf in Sustaining of Indonesian Society "In Legal \&amp; Economic Perspective". AL-ITQAN: JOURNAL OF ISLAMIC SCIENCES AND COMPARATIVE STUDIES, IRKHS-IIUM, Malaysia, 2(1), 83-97. https://doi.org/10.31436/al-itqan.v2i1.43
} 
accepted as the customary law of the Indonesian nation itself. Because waqf can solve various problems of economic, social, social, administrative and even political matters.

The development of waqf in Indonesia can be traced from the 12th century to the 14th century $\mathrm{AD}$, the influence of Sufi wanderers in developing Islamic teachings. The proof is the role of walisongo when introducing Islam and spreading Islam in the palace environment, the guardians usually start by establishing pesantren and mosques in their environment. Since Islam is known by the Indonesian people, waqf arrangements are subject to Islamic law. The procedure for waqf of land is carried out based on the provisions of fiqh contained in the yellow books, very simple and sufficient only with the waqf pledge from Wakif to Nadzir only. Then during the colonial period, a government was formed under Dutch rule, so every act of waqf of land must be known by the state. As for the regulated waqf property, only limited to immovable objects in the form of land, does not regulate movable waqf property even though at that time there were already waqf of the Qur'an, prayer mats, and bricks. During his reign in Indonesia, the colonial government issued several policies regarding waqf regulations ${ }^{9}$, where between 1903-1935, the Dutch regulated waqf activities, including: ${ }^{10}$

- The Dutch government has controlled waqf activities through mandatory registration, as well as having to ask permission from the Regents to donate wealth as waqf.

- The regent is given the authority to handle cases related to waqf disputes. In general, waqf legal provisions only regulate authority, licensing, land registration, and other administrative matters, so as not to conflict with the interests of the government at that time.

\subsubsection{Waqf Regulations for the Independence Period Until Government Regulation} No. 28 of 1977 concerning Waqf of Owned Land

After Indonesia's independence, waqf regulations are increasingly developing in a positive direction. Exactly five months after Indonesia's independence, namely on January 3, 1946, the Ministry of Religion was established based on the Decree of the President of the Republic of Indonesia. The main task of the Ministry of Religion is to accommodate religious affairs and regulate activities based on its teachings, so since then waqf has become the authority of the Ministry of Religion. With the existence of this Government Regulation, the waqf of owned land has begun to enter a new phase. With the stipulation of government regulations regarding waqf has a strong legal basis. Because during that time, the regulations governing waqf were inadequate so that many waqf problems arose in the community, such as many land disputes, land status was unclear, the situation was unknown, misuse of waqf property, etc. The regulations at this time were not perfect as a whole, but only regulates the procedures for waqf property, not regulating other waqf assets. The priority of waqf arrangements that are very prioritized is land at this time, which has a very important role, both as a place to

\footnotetext{
${ }^{9}$ Ali Achmad Chomzah, (2002), Hukum Pertanahan; Pemberian Hak Atas Tanah Negara, Sertipikat dan Permasalahannya, Jakarta: Prestasi Pustaka, p.31

${ }^{10}$ Djunaidi, Achmad, et.all, (2006), Perkembangan Pengelolaan Wakaf di Indonesia, Jakarta: Direktorat Pemberdayaan Wakaf, p. 16
} 
live, a place of worship, a place of education, a place for office activities, a place for trading business activities, agriculture, animal husbandry and others. With the very rapid development of development in various fields, which resulted in the emergence of various kinds of interests from various parties, the role of the state in regulating land ownership is very necessary. Even though this government regulation has been issued, in its journey the existing waqf regulations have not run effectively in controlling waqf. To that end, on November 30, the Joint Instruction of the Minister of Religion and the Head of the National Land Agency No. 4 of 1990 and No. 24 of 1990 concerning Waqf Land Certificates.

\subsubsection{Presidential Instruction No. 1 of 1991 concerning the Compilation of Islamic Law}

As it is known that during the technical development of the Religious Courts, it was felt that there were several weaknesses and problems, including the question of Islamic law applied in the Religious Courts, which tended to be confusing. This is due to the difference of opinion of the Ulama on every issue. To overcome this problem, on February 5, 1991, Presidential Instruction No. 1 of 1991 concerning the Compilation of Islamic Law (KHI). This instruction issued is a guideline for government agencies and the public who need it in solving problems in the field of waqf, especially those contained in book III. Then, this Presidential Instruction was followed up with the Decree of the Minister of Religion No. 154 July 22, 1991. Here the government asks all agencies within the Ministry of Religion including the Religious Courts to disseminate KHI. Several expansions related to waqf rules in the KHI are related to waqf objects, nazir and so on. Regarding waqf objects, for example, it includes movable property. Likewise, nazir is no longer limited, but adapted to the needs of waqf management. After several laws and regulations relating to waqf issues, the reality is seen from the orderly administration, waqf has increased because there are quite a number of certified waqf lands, but the impact on the socio-economic welfare of the community is not yet visible. The problem is caused by waqf which is regulated in Government Regulation No. 28 of 1977 only owned land, while waqf in the form of movable objects has not been regulated. Because there are no regulations for movable objects, waqf in this country is quite difficult to develop productively. On the other hand, the presidential instructions contained in book III have not been sufficient to revitalize the waqf sector. This is due to the fact that KHI still adopts the old literal paradigm and follows the old fiqh guidelines. Then after some time the government realized about these shortcomings, the Ministry of Religion of the Republic of Indonesia along with the Ulema Council and other parties tried to strengthen the management of waqf land from traditional management to professional and productive management by explaining waqf law to the public, drafting a bill on waqf in accordance with with the development of time,

\subsubsection{Waqf in Act No. 41 of 2004 concerning Waqf}

In line with the rolling wave of reform and democratization at the end of the 1990 s, bringing changes so as to strengthen Islam as one of the political powers on the national stage, until the emergence of a law that specifically regulates waqf. The Government of the Republic of Indonesia recognizes the existence of legal rules for waqf in the form of a law during the reformation period Act No. 42 of 
2004 and Government Regulation No. 42 of 2006 concerning the Implementation of Waqf. This law stipulates that the Waqf Institution as a religious institution that has economic potential and benefits that must be managed effectively and efficiently for the benefit of worship and to promote the general welfare that has been living and implemented in society for a long time, whose arrangements are not yet complete and are still scattered in various laws and regulations and at the same time to meet legal needs in the context of developing national law in the field of waqf. In addition, with the ratification of this Law, the object of waqf is wider in scope, not only limited to immovable objects such as the establishment of places of worship and religious social, but also includes movable objects such as money, precious metals, securities, rental rights and others. Then, in terms of regulations governing government intervention in waqf, it is only in the nature of recording and supervising the maintenance of waqf objects so that they are in accordance with the aims and objectives of the waqf. The government does not interfere in, and control, or make waqf objects as state property. With the enactment of the 2004 Waqf Law, The ummah's political agenda shifts from an ideological orientation towards a strong socio-economic vision on a national scale, the state will take into account the various aspirations, negotiations, and movements of Muslims. With the regulation of waqf in the form of a law in Indonesia, the waqf sector can be functioned more towards improving the socio-economic welfare of the people.

\subsubsection{Waqf in Government Regulation No. 42 of 2006}

Government regulations are needed by Nadzir in managing waqf, especially cash waqf. This is understandable, because currently there are several Nadzir who have managed cash waqf and productive waqf. Waqf Savings and Baitul Mal Muamalat, for example, they have received cash waqf from the wakif, to later develop and distribute the results to the mauquf 'alaih. With the Government Regulation, the Nadzirs have a strong foundation in carrying out their duties. Ease and security in the implementation of waqf, especially cash waqf, is very important, considering the large number of Muslim residents who want to donate money to be later developed by Nadzir, so that mauquf 'alaih immediately gets the results of the development of the waqf. ${ }^{11}$

\subsection{History of Waqf Regulation Based on National Legal Politics}

Etymologically, waqf comes from the Arabic word al-waqf, this word has the same meaning as the word al-habs, which means "to hold back". ${ }^{12}$ In terms of terminology, there are several editorials put forward by fiqh scholars in defining the word waqf. In the book of fiqh al-Sunnah, it is stated that al-waqf is holding back wealth and giving mandates in the way of Allah. ${ }^{13}$. In addition, there are several editors who agree with this definition, namely holding back the origin of assets and carrying out the results; withhold or stop assets that can be used for the benefit of goodness to draw closer to Allah; hold an object and carry out its

\footnotetext{
${ }^{11} \mathrm{Ibid}$, p. 65-88.

${ }^{12}$ Sayyid Sabiq, (tt.), Fiqh Al-Sunnah, Juz III, Beirut: Dar al-Fikr, p.515

13 Ibid
} 
benefits by using the word "I am waqf" or "I am holding back" or a word that is similar to it ${ }^{14}$. In KHI jo. Article 1 (1) PP.No.28/1977 waqf is defined as follows: "The legal act of a person or group or legal entity that separates part of his property and symbolizes it forever for the benefit of worship or other public purposes in accordance with Islamic teachings" 15 . Thus, waqf covers the following issues:

- Property belonging to a person or group of people;

- The property is eternal in substance, does not run out when used;

- The ownership of the property is released by the owner;

- The property whose ownership is released cannot be donated, inherited, or traded;

- The benefits of these assets are for the public interest in accordance with Islamic teachings

The paradigm of planning for productive waqf management has actually been exemplified by the Prophet who ordered Umar bin Khattab to endow his plot of land in Khaibar. The substance of the Prophet's orders is to emphasize the importance of the existence of waqf objects and to manage them professionally. While the results are used for the benefit of general virtue (ihbis ashlaha wa tashaddaq tsamarataha). The most easily understood understanding of the Prophet's intention is that the substance of the waqf teaching does not solely lie in the immortality of the object, but the extent to which the waqf object provides benefits to the mauquf 'alaih (the target of the waqf), and the value of the benefit of the waqf object can be obtained optimally if managed productively. If we consistently hold to the meaning of the Prophet's hadith above, then there should be no abandoned waqf objects, let alone burden the Nadzir. That there are some scholars who insist on understanding waqf more to the integrity of the object even though it has been damaged or does not provide benefits though, that is another matter.

However, the basic principles of waqf itself have actually been taught by the Prophet as above. Therefore, productive waqf empowerment must be made a joint movement in order to build a just economic sector of the people. Especially in the midst of our efforts to get out of the economic crisis that has entangled this nation for a long time. In essence, it is never too late for us to reorganize the management of waqf in order to provide more social welfare, both in the fields of education, health, economy, worship facilities and so on. The existence of waqf in the social constellation of society is highly coveted, because the waqf institution in Islamic teachings is essentially not only a shock breaker to overcome temporary needs, but is expected to be a sub-system of the Baitul Mal institution.

Waqf if managed professionally will be a potential source of funds for the development of the nation and state. The practice of waqf in Indonesia has not yet been fully and efficiently run so that in many cases many waqf assets are neglected and or not maintained, not even a few have turned to third parties by way of

\footnotetext{
${ }^{14}$ Ahmad Rofiq, 1977, Hukum Islam di Indonesia, Print. II; Jakarta: Raja Grafindo Persada, p. 490491

15 Director of the Development of Religious Courts, Compilation of Islamic Law in Indonesia, 1998/1999, p.99
} 
violating the law, especially when the need for land / land is increasing in relation to population development of human and natural exploration. This could be due to Nadzir's inability to manage and develop waqf assets in addition to the lack of public understanding of the functions, objectives and parameters of waqf assets according to the Shari'a.

In addition to the reasons as mentioned above, the scope of waqf which has been understood by the public tends to be limited to immovable objects such as land and buildings, even though this is not the case, waqf can also be in the form of movable objects such as vehicles, as well as intangible objects, namely money, precious metals. , securities can even be waqf in the form of rights, for example intellectual property rights. To realize and revitalize waqf in Indonesia, the government has provided a legal umbrella in the field of waqf with the instrument of law, namely Act No. 41 of 2004 promulgated on October 27, 2004 with the aim that all elements involved with waqf have a legal umbrella in utilizing waqf assets.

From the perspective of legal politics, waqf in Indonesia is regulated by three legal instruments, namely: the first with the Government Regulation Instrument Number 28 of 1977, then the second with the Impres Instrument, namely the Compilation of Islamic Law (KHI) and the last with the Law Instrument Number 41 of 2004. This indicates that the Indonesian government pays serious attention to waqf institutions and implies the government's seriousness to strengthen Islamic law institutions into national law in the form of legal transformation. There are several things that become the main idea of the law, covering at least five principles; First; To create legal order and waqf administration in order to protect waqf property, Second: The scope of waqf which has been generally understood so far tends to be limited to waqf of immovable objects such as land and buildings, according to this law waqf can also donate part of wealth in the form of movable property, both tangible and intangible, namely money, precious metals, securities, vehicles, intellectual property rights, rental rights and other movable objects; In the case of movable objects in the form of money, the wakif can donate it through a Sharia Financial Institution. What is meant by Sharia Financial Institutions here are Indonesian legal entities established in accordance with the prevailing laws and regulations that are engaged in sharia finance, for example legal entities in the sharia banking sector.

Third: The allocation of waqf property is not only for the sake of religious and social facilities, but can also be intended to promote public welfare by realizing the potential and economic benefits of waqf property. Therefore, it is very possible to manage waqf property for economic activities in a broad sense as long as the management is in accordance with the principles of management and shariah economics; Fourth: In order to secure the waqf property from the interference of third parties that harm the interests of the waqf, it is necessary to improve the professional ability of Nadzir; Fifth; This law also regulates the formation of the Indonesian Waqf Board which can have representatives in the regions as needed. The agency is an independent institution that carries out tasks in the field of waqf which provides guidance to Nadzir ${ }^{16}$.

${ }^{16}$ Explanation of Act No. 411 of 2004 concerning Waqf 
There are two other things that are no less important which are the principles of waqf issues that must be a reference, namely: waqf was originally intended for the welfare of the people, because if you look at the history and practice of waqf at the time of the prophet Muhammad SAW, it turns out that the existence of waqf is very potential and determines the smooth running of the economy that brings prosperity to the people, and when someone has donated something, then he can no longer take back the goods that are waqf. This last point is important to maintain the permanence of the waqf property and ensure its legal certainty. In the Compilation of Islamic Law Article 215 paragraph (4) states that: "Waqf objects are all objects, both movable and immovable objects that have durability that are not only disposable and have value according to Islamic teachings". Then article 217 paragraph (3) states that: Waqf objects as referred to in Article 215 paragraph (4) must be property that is free from all encumbrances, bonds, confiscations and disputes. Meanwhile, in Government Regulation number 28 of 1977 Article 4 states: "Land as referred to in Article 3, must be property rights or land that is free from all encumbrances, bonds, confiscations and cases". In several narrations it is stated that some jurists such as Imam Az-Zuhri also argue that it is permissible to donate dinars and dirhams, the implementation is that the dinars and dirhams are used as business capital (trade) then distribute the profits as waqf. Meanwhile, in Government Regulation number 28 of 1977 Article 4 states: "Land as referred to in Article 3, must be property rights or land that is free from all encumbrances, bonds, confiscations and cases".

In several narrations it is stated that some jurists such as Imam Az-Zuhri also argue that it is permissible to donate dinars and dirhams, the implementation is that the dinars and dirhams are used as business capital (trade) then distribute the profits as waqf. Meanwhile, in Government Regulation number 28 of 1977 Article 4 states: "Land as referred to in Article 3, must be property rights or land that is free from all encumbrances, bonds, confiscations and cases". In several narrations it is stated that some jurists such as Imam Az-Zuhri also argue that it is permissible to donate dinars and dirhams, the implementation is that the dinars and dirhams are used as business capital (trade) then distribute the profits as waqf.

According to the Hanafi Madhhab, the waqf money is used as business capital with a mudlarabah or murabahah system and other profit-sharing systems that are legal according to syar'i. The profit from the profit sharing is given for the public interest. Looking at the principles in the waqf laws and regulations both contained in Government Regulation No. 28 of 1977, the Compilation of Islamic Law (KHI) and Act No. 41 of 2004 above, it appears that these laws and regulations are in sync with the opinions of the schools known in Islamic jurisprudence. Even the existence of waqf regulations has at least provided an understanding of the breadth of the scope of waqf objects as well as providing legitimacy for the strength and legal certainty of waqf; For example, regarding the provisions on the obligation to register waqf land, conditions for Nadzir and so on.

Waqf is a religious institution that has high economic value, if it is managed professionally, its existence becomes a source that can support the economy of the people. We can reflect on the Al-Azhar waqf which is able to help government finances when there is a monetary crisis. Attention and professional development of waqf managers is something that is determined, then with the issuance of Act 
No. 41 of 2004 concerning waqf, on the one hand, will provide legitimacy for the existence of waqf bodies, but more importantly, the existence of the Waqf Law will bring more order to the administration of waqf as well as strengthen the implementation of some Islamic laws in Indonesia.

\section{Conclusion}

A comparison of waqf legislation during the Dutch era to the reform era can be concluded that in terms of the concept of waqf, Act No. 5 of 1960 has provided an opportunity for waqf in Indonesia. The peak of the waqf concept can be seen in Act No. 41 of 2004 which is equipped with PP No. 42 of 2006. In terms of wakif and nazhir, the initial concept has been introduced in PP No. 28 of 1977 and confirmed by KHI. However, the latest version has been mentioned in Act No. 41 of 2004 and PP No. 42 of 2006, such as the existence of wakif and Nadzir organizations. Furthermore, the concept of waqf property underwent significant changes. If in PP No. 28 of 1977 waqf property is limited to land owned, Act No. 41 of 2004 and PP No. 42 of 2006 provides the breadth of the types of waqf objects consisting of immovable objects and movable objects.

\section{References}

\section{Journals:}

[1] Hadi Solikhul, 2014, "Regulasi UU Nomor 41 Tahun 2004 Tentang Wakaf (Tinjauan Sejarah-Sosial)”, Jurnal Penelitian, Vol. 8, No. 2 August, from https//:journal.iainkudus.ac.id

[2] Ong Argo Victoria, "Waqf Al-Nuqūd In Indonesia (In Law Perspective)”, Jurnal Pembaharuan Hukum Vol 5, No 1 Universitas Sultan Agung, http://jurnal.unissula.ac.id/index.php/PH/article/view/2999

[3] Pradikta Andi Alvat, "Politic of Law Human Rights Protection", Indonesia $\begin{array}{llll}\text { Jurnal Daulat Hukum } & \text { Vol.2 }\end{array}$ url:http://jurnal.unissula.ac.id/index.php/RH/issue/view/398

[4] Sukarmi, S., \& Victoria, Argo, "Cash Waqf in Sustaining of Indonesian Society In Legal \&amp; Economic Perspective". AL-ITQAN: JOURNAL OF ISLAMIC SCIENCES AND COMPARATIVE STUDIES, IRKHS-IIUM, Malaysia, 2(1), 83-97. https://doi.org/10.31436/al-itqan.v2i1.43

\section{Books:}

[1] Abdulrahman, 1994, Masalah Perwakafan Tanah Milik \& Kedudukan Tanah Wakaf di Negara Kita, Bandung: Citra Aditya Bakti

[2] Adijani AI-Alabij, 1989, Perwakafan Tanah dl Indonesia Dalam Teori dan Praktek, Jakarta: Rajawali

[3] Ahmad Azhar Basyir, 1987, Hukum Islam tentang Wakaf, Ijarah Syirkah, Bandung: Alma'arif

[4] Ahmad Chulemi, 1987, Hukum Agraria Perkembangan Macam-Macam Hak Atas Tanah dan Pemindahannya, Semarang: Faculty of Law UNDIP

[5] Ahmad Rofiq, 1977, Hukum Islam di Indonesia, Print. II; Jakarta: Raja Grafindo Persada 
[6] Ali Achmad Chomzah, 2002, Hukum Pertanahan; Pemberian Hak Atas Tanah Negara, Sertipikat dan Permasalahannya, Jakarta: Prestasi Pustaka

[7] Djunaidi, Achmad, et.all, 2006, Perkembangan Pengelolaan Wakaf di Indonesia, Jakarta: Direktorat Pemberdayaan Wakaf

[8] Padmo Wahjono, 1986, Indonesia Negara Berdasarkan Atas Hukum, Jakarta: Ghalia Indonesia

[9] Sayyid Sabiq, (tt.), Fiqh Al-Sunnah, Juz III, Beirut: Dar al-Fikr

\section{Regulation:}

[1] Act No. 41 of 2004 concerning Waqf

[2] Inpres No. 1 of 1991 on Compilation of Islamic Law (KHI) 